\title{
RELATIONSHIP BETWEEN CONDENSED TANNINS AND DRY MATTER DEGRADABILITY OF TWO TROPICAL FODDER LEGUMES
}

\author{
${ }^{1} \mathrm{~T}$ Seresinhe, ${ }^{2} \mathrm{C}$ Iben and ${ }^{1} \mathrm{KK}$ Pathirana \\ 'Department of Animal Science, Faculty of Agriculture, \\ University of Ruhuna. Mapalana \\ ${ }^{2}$ Department of Nutrition, University of Vetrinary Medicine, Vienna, Austria
}

In the tropics tree fodder legumes provide adequate protein to ruminants, particularly in the dry season. However, many of them contain high levels of anti nutritional factors such as condensed tannins. Therefore, the objective the present study was to investigate the relationship between condensed tannin (CT) content and the in vitro dry natter digestibility (DMD) of two tropical shrubs, Gliricidia sepium and Calliandra calothyrsus. The tannin binding chemical polyethylene glycol (PEG) was added at rates of 0.1500 and $500 \mathrm{hmg} / 100 \mathrm{~g}$ plant substrate to asses the effect on DMD.

Although the PEG response was not marked, G. sepizm had significantly $(\mathrm{P}<0.05)$ higher DMD $(60 \%-65 \%)$ in all treatments as compared with C. calothyrsus. In contrast, DMD of C. calothyrsus increased $(39.5 \%$ to $53.5 \%)$ with the addition of PEG. Extractable CT levels ranged from $0.57 \%$ in $G$. sepium to $4.05 \%$ in C. calothyrsus. Results indicate that $C$. calothyrsus in spite of having a lower DMD due to high levels of condensed tannins, the addition of PEG had a significantly higher and desirable effect on DMD corrpared to $G$. sepium.

The significant co-correlation of DMD and CT inticates that PEG binding technique is a suitable method to improve the dry matter degradability of tannin rich tropical forages. 